\title{
BIOANALYSIS OF TOTAL PHENOLIC CONTENTS, VOLATILE COMPOUNDS, AND RADICAL SCAVENGING ACTIVITIES OF THREE WILD EDIBLE MUSHROOMS
}

\author{
AHMET METIN KUMLAYa, MEHMET ZEKI KOÇAK ${ }^{\text {, }}$ \\ MUBIN KOYUNCUc, UĞUR GÜLLER ${ }^{\mathrm{c},{ }^{*}}$
}

\begin{abstract}
Mushrooms are popular food for a long time because of their high nutritional value and many pharmaceutical properties. In that context, analyzing the contents and some antioxidant properties of three wild edible mushrooms, Paxina queletii, Chlorophyllum agaricoides, and Mycenastrum corium, is important in terms of emphasizing the values of these species in nutrition. For this propose, firstly total phenolic and flavonoid contents and radical scavenging activities were assayed. Then, quantitative analysis of phenolic and volatile compounds was performed by HPLC and GC-MS. The findings of the study revealed that Mycenastrum corium has the highest total phenolic and flavonoid content with the amount of $4.17 \mathrm{mg} \mathrm{GAE} / \mathrm{g}$ and $1.58 \mathrm{mg} \mathrm{QE} / \mathrm{g}$ respectively. However, $\mathrm{DPPH}^{\circ}$ and $\mathrm{ABTS}^{++}$radical scavenging activities of $C$. agaricoides were found higher with the $\mathrm{IC}_{50}$ values of $20.0 \mu \mathrm{g} / \mathrm{mL}$ and $6.4 \mu \mathrm{g} / \mathrm{mL}$. Chromatographic analysis revealed that 5 alcohols, 14 aldehydes and ketones, 2 esters, 17 alkanes-heterocyclic compounds, and 4 acids were the major contributors of the antioxidant activities of the extracts. Regarding HPLC analysis, gallic acid, naringin and trans-cinnamic were found to be major phenolic compounds available for three species.
\end{abstract}

Keywords: Chlorophyllum agaricoides, volatile compounds, Mycenastrum corium, Paxina queletii, phenolic content, radical scavenging

\section{INTRODUCTION}

Mushrooms are functional foods that can provide additional benefits to human physiology and metabolic functions beyond meeting the essential nutrients. So, they can show effectiveness in preventing diseases [1]. Fungi

a Iğdır University, Faculty of Agriculture, Department of Field Crops, Iğdır, Turkey

b Iğdır University, College of Applied Science, Department of Organic Farming, Iğdır, Turkey

c Iğdır University, Faculty of Engineering, Department of Food Engineering, Iğdır, Turkey

Corresponding author: ugur.guller@igdir.edu.tr 
are a large family of eukaryotic organisms. Mushrooms are generally accepted as macrofungi with distinctive fruit parts that can be seen with the naked eye and can be collected by hand [2]. It has been estimated that more than 5.1 million different types of mushrooms are available [3]. Mushrooms are generally divided into two groups as medicinal and edible and have become more remarkable due to their nutritious, medicinal and economic potential [4].

In addition to their high-protein (200-250 g/kg dry matter), low-fat (20$30 \mathrm{~g} / \mathrm{kg}$ dry matter) and low energy (240-310 kcal $/ \mathrm{kg}$ ) content they are good source of dietary fiber (220-300 g/kg dry matter) and sources of vitamins and minerals $[5,6] .70 \%$ of the protein in mushrooms can be easily digested by the body [7]. Mushrooms are an important protein source for vegetarians because the proteins of some species are nutritionally equivalent to muscle proteins and they contain some essential amino acids found in animal proteins [8, 9]. Many mushroom species have been reported to contain L-ergothioneine, an important antioxidant, 12 times more than wheat germ and 4 times more than chicken liver [10-15]. The antioxidant potential of mushrooms is due to the rich phenolic compound contents [16-18]. Mushrooms are rich in B-group vitamins (folic acid, cobalamin, niacin, pantothenic acid, pyridoxine, thiamine, and riboflavin), ergosterol, phytoquinone, and tocopherols. Moreover, they are the only non-animal source of vitamin $D$ in edible form [19-21]. It has also been reported that mushrooms are the source of beta-glucan, a polysaccharide preferred in cancer and HIV treatments because of its antitumor effects $[22,23]$. Besides they are rich in mineral composition. Basic minerals known in their composition are calcium, potassium, iron, copper, and zinc. Potassium and phosphorus concentrations are higher than most vegetables, and most importantly are selenium contents not found in many fruits or vegetables [24].

When evaluated from a medical point of view, many types of fungi have been reported to contain substances that can prevent or alleviate cancer, heart disease, diabetes, viral infections, hypertension and hypercholesterolemia [25-27]. Besides, many medical benefits have been attributed to mushroom consumption, including the treatment of chronic and degenerative diseases, obesity, and cardiovascular disease [28, 29]. Due to the importance of mushrooms' nutritional content, in this study, the research team aimed to reveal the chemical composition and radical scavenging activities of three wild edible mushrooms, namely Paxina queletii, Chlorophyllum agaricoides, Mycenastrum corium.

\section{RESULTS AND DISCUSSION}

As a result of in vivo and in vitro experiments, it has been reported that mushrooms have bioactive substances (phenolics, antioxidants, antiinflammatory, and antitumor agents) that are beneficial for health. Due to 
their bioactive content, fungi show antibacterial, antifungal, antioxidant, antiviral, antitumor, cytostatic, immunosuppressive, antiallergic, antiatherogenic, hypoglycemic, anti-inflammatory and hepatoprotective activity [37]. Therefore, it is possible to be protected from diseases with a well-balanced diet associated with mushroom consumption due to the beneficial nutritional content of them [24, 38-40]. So in this study, total phenolic contents (TPC), total flavonoid contents (TFC), radical scavenging ability, volatile compounds and phenolic acid compositions of Paxina queletii, Chlorophyllum agaricoides, Mycenastrum corium were analyzed by using spectrophotometric and chromatographic methods to clarify their nutritional value.

TPC in ethanolic extracts of mushrooms (Paxina queletii, Chlorophyllum agaricoides, Mycenastrum corium) were found as $2.94 \pm 0.58,1.36 \pm 0.35$, and $4.17 \pm 0.67 \mathrm{mg} \mathrm{GAE} / \mathrm{g}$ respectively (Table 1 ).

Table 1. DPPH ${ }^{*}$ and $\mathrm{ABTS}^{-+}$radical scavenging activity, total phenolic and total flavonoid contents of mushroom extracts.

\begin{tabular}{|l|c|c|c|c|}
\hline $\begin{array}{l}\text { Mushroom } \\
\text { Species }\end{array}$ & $\begin{array}{c}\text { Total Phenolic } \\
\text { Content } \\
(\mathbf{m g} \text { GAE/g) }\end{array}$ & $\begin{array}{c}\text { Total Flavonoid } \\
\text { Content } \\
(\mathbf{m g} \text { QE/g) }\end{array}$ & $\begin{array}{c}\mathbf{I C}_{50} \text { for DPPH } \\
\text { Radical } \\
\text { Scavenging } \\
(\boldsymbol{\mu g} / \mathbf{m L})\end{array}$ & $\begin{array}{c}\text { IC } \\
\text { Ro for ABTS } \\
\text { Radical } \\
\text { Scavenging } \\
(\boldsymbol{\mu g} / \mathbf{m L})\end{array}$ \\
\hline P. queletii & $2.94 \pm 0.58$ & $1.0 \pm 0.15$ & 27.5 & 7.2 \\
\hline C. agaricoides & $1.36 \pm 0.35$ & $0.49 \pm 0.06$ & 20.0 & 6.4 \\
\hline M. corium & $4.17 \pm 0.67$ & $1.58 \pm 0.62$ & 25.9 & 7.5 \\
\hline Ascorbic acid & - & - & 1.4 & 1.59 \\
\hline Trolox & - & - & - & 2.15 \\
\hline
\end{tabular}

The results of the current study were found lower than formerly reported studies. Liu et al. (2017) reported that TPC in different solvent fractions of Inonotus sanghuang ranged from 0.79 to $43.60 \mathrm{mg} \mathrm{GAE} / \mathrm{g}$ [41]. Smolskaitè et al. (2015) determined that TPC in various organic solvent extracts of eight mushroom species ranged from 4.21 to $31.88 \mathrm{mg} \mathrm{GAE} / \mathrm{g}$ [42]. Besides, our results appeared similar with the ethanolic extract of $A$. bisporus $(6.18 \mathrm{mg}$ $\mathrm{GAE} / \mathrm{g}$ ) and methanolic extract of $A$. bisporus (3.4 mg GAE/g dw) [43]. Specifically, Sezgin et al. (2020) reported that TPC value for Chlorophyllum agaricoides was reported as $46.5 \pm 1.4 \mathrm{mg}$ equivalent (eq.) GA /g DW [44]. Those values were relatively much higher than those of values in the present study but higher than the report of Azieana et al. (2017) and our findings were similar to the report of López-Vázquez et al. $(2017)[45,46]$. Different from the 
study conducted by Sezgin et al. (2020) [44], we also carried out DPPH' and $\mathrm{ABTS}^{*+}$ radical scavenging activities and characterized total flavonoid content with respect to quercetin equivalent of Chlorophyllum agaricoides.

Furthermore, TFC contents were $1.0 \pm 0.15,0.49 \pm 0.06$, and $1.58 \pm 0.62$ mg equivalent $\mathrm{QE} / \mathrm{g} \mathrm{DW}$ for $P$. queletii, C. agaricoides and $M$. corium, respectively. As the case of total phenolic reports, TFC values of the current study was lower in comparison with the previous reports in different mushroom species analyzed by Abugri and Mc Elhenney (2013) but higher than the report by Azieana et al. (2017) and the current values were relatively close to the former reports [45, 47-49].

We performed $\mathrm{DPPH}^{-}$and $\mathrm{ABTS}^{-+}$assays to determine the radical scavenging activities of the relevant mushroom species. Through the ability to donate hydrogen, antioxidants can reduce the $\mathrm{DPPH}^{\circ}$ radical (purple) to the non-radical form DPPH-H (yellow) [43]. In order to compare the percentage of radical scavenging potencies with standards, radical scavenging $\%$ were calculated at a constant concentration $(3 \mu \mathrm{g} / \mathrm{ml})$. At $3 \mu \mathrm{g} / \mathrm{ml}$ concentration, $\mathrm{DPPH}^{*}$ radical scavenging activity\% of the ethanolic extract of Paxina queletii, Chlorophyllum agaricoides, Mycenastrum corium, and standard ascorbic acid were found $13.19 \%, 14.32 \%, 9.2 \%$, and $95.44 \%$ respectively. These results indicated that $\mathrm{DPPH}^{*}$ scavenging abilities of mushroom samples are lower than standard chemicals (Figure 1).
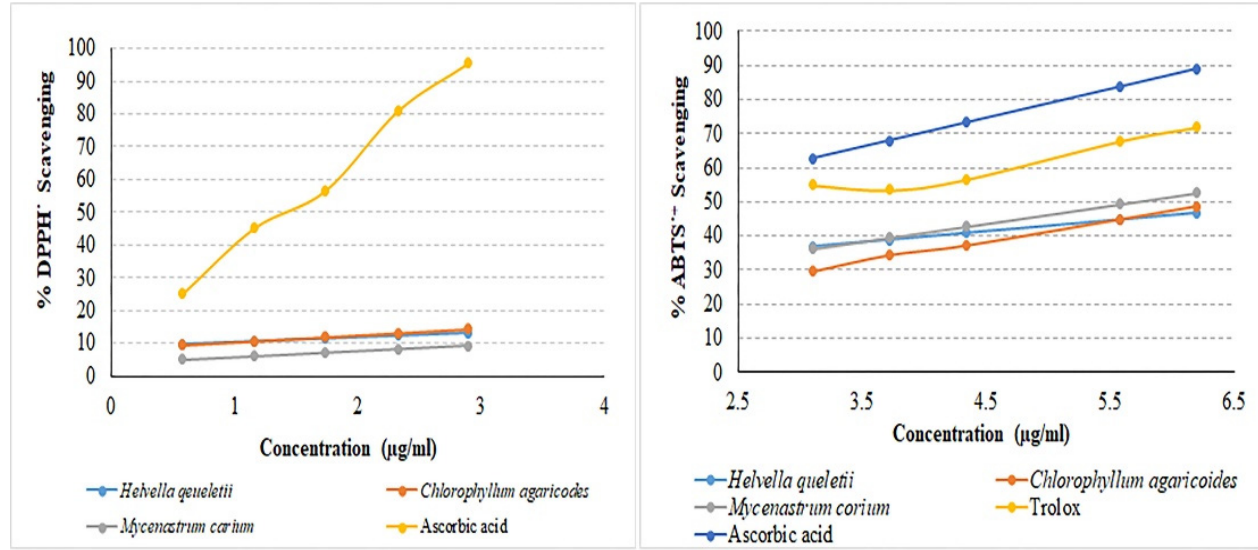

Figure 1. DPPH ${ }^{*}$ and $\mathrm{ABTS}^{-+}$radical scavenging activities of the relevant mushroom species and standards 
The $\mathrm{IC}_{50}$ values of mushroom extracts and standard were $27.5,20.0$, 25.9 , and $1.4 \mu \mathrm{g} / \mathrm{ml}$ respectively (Table 1 ). DPPH scavenging abilities of mushroom samples are higher than extracts of $A$. bisporus [50-53] and lower than the ethanolic extract of $I$. Sanghuang [41]. DPPH' radical scavenging activity of ethanolic extract of $P$. queletii were found considerably higher than methanolic extract of it (87.65\% of $20 \mathrm{mg} / \mathrm{ml}$ extract) [54].

At $3 \mu \mathrm{g} / \mathrm{ml}$ concentration of samples and standards, ABTS ${ }^{++}$radical scavenging activity $\%$ of the ethanolic extract of Paxina queletii, Chlorophyllum agaricoides, Mycenastrum corium, trolox and ascorbic acid were determined as $36.84,29.67,36.31,54.954$, and $62.76 \%$ respectively. ABTS ${ }^{+}$scavenging activity of all mushroom extract were lower than that of both standards (Figure 1). The $\mathrm{IC}_{50}$ values of ethanolic extracts of mushroom samples and standards were $7.2,6.4,7.5,1.59$, and $2.15 \mu \mathrm{g} / \mathrm{ml}$ respectively (Table 1 ). The results of this study are close to those of G. lucidum, G. esculenta, L. decastes, $P$. ostreotus, and $F$. trogii, collected from Uşak, western Turkey, that reporting $\mathrm{IC}_{50}$ values was found in the range of $1.27-192.1 \mu \mathrm{g} / \mathrm{ml}$ [55]. Besides, ABTS $^{*+}$ scavenging activities of Paxina queletii, Chlorophyllum agaricoides, and Mycenastrum corium determined higher than those of I. Sanghuang [55] and Armillaria tabescens, Leucopaxillus gentianeus and Suillus granulates methanolic extracts. Tel et al. (2014) reported the ABTS'+ radical scavenging activity \% of mushroom species at issue, in the range between $12.73 \%-79.86 \%$ for $50 \mu \mathrm{g}$ extracts [56].

A total of 42 compounds were detected by SPME/GC-MS, including 5 alcohols, 14 aldehydes and ketones, 2 esters, 17 alkanes-heterocyclic compounds, and 4 acids (Table 2). Similar volatile compound groups have been identified in many studies on mushrooms [35, 57-59]. Of those relevant components, volatile compounds common to mushroom samples are hexanal, nonanal, and dodecane. The main volatiles in Mycenastrum corium was nonanoic acid $(22.40 \%)$ and 2-pentylfuran (15.71\%). 2-pentylfuran (16.30\%) and hexanal $(16.21 \%)$ in Paxina queletii, and benzaldehyde $(26.50 \%)$ in Chlorophyllum agaricoide were the main volatile compounds.

Paxina queletii has the highest content of alcohols and aldehydesketones compared to the other mushrooms. The highest content of alkanesheterocyclic compounds is in Chlorophyllum agaricoides, and the highest acid content is in Mycenastrum corium. This content difference of volatile components in mushrooms reveals the unique character of each one. Mycenastrum corium and Paxina queletii have almost the same amount of 2-pentylfuran. 
Table 2. Volatile compounds of Mycenastrum corium, Paxina queletii, and Chlorophyllum agaricoides

\begin{tabular}{|c|c|c|c|c|c|c|}
\hline & & & & $\begin{array}{c}\text { Mycenastrum } \\
\text { corium }\end{array}$ & $\begin{array}{l}\text { Paxina } \\
\text { queletii }\end{array}$ & $\begin{array}{c}\text { Chlorophyllum } \\
\text { agaricoides }\end{array}$ \\
\hline No & $\mathrm{RT}^{\mathrm{a}}$ & Compound Name & $\begin{array}{c}\text { Cas } \\
\text { Number }\end{array}$ & \multicolumn{3}{|c|}{ Area $\%^{\mathrm{b}}(\mathrm{SD})^{\mathrm{c}}$} \\
\hline \multicolumn{7}{|l|}{ Alcohols } \\
\hline 1 & 4.16 & 1-Butanol, 3-methyl- & $123-51-3$ & $0.91 \pm 0.05$ & - & - \\
\hline 2 & 6.45 & 1-Hexanol & $111-27-3$ & $0.63 \pm 0.02$ & - & - \\
\hline 3 & 9.58 & 1-Octen-3-ol & $3391-86-4$ & - & $9.21 \pm 1.12$ & - \\
\hline 4 & 11.02 & 1-Hexanol, 2-ethyl- & $104-76-7$ & $6.43 \pm 0.11$ & - & - \\
\hline 5 & 12.29 & 1-Octanol & $111-87-5$ & $1.18 \pm 0.08$ & $3.09 \pm 0.66$ & - \\
\hline \multicolumn{2}{|c|}{ Total alcohols } & & & 9.15 & 12.30 & - \\
\hline \multicolumn{7}{|c|}{$\begin{array}{c}\text { Aldehydes- } \\
\text { ketones }\end{array}$} \\
\hline 6 & 4.81 & Hexanal & $66-25-1$ & $5.76 \pm 0.90$ & $16.21 \pm 0.05$ & $2.94 \pm 0.05$ \\
\hline 7 & 6.98 & 2-Heptanone & $110-43-0$ & $2.29 \pm 0.60$ & $9.04 \pm 0.98$ & - \\
\hline 8 & 7.33 & Heptanal & 111-71-7 & $0.81 \pm 0.05$ & - & - \\
\hline 9 & 9.03 & Benzaldehyde & $100-52-7$ & - & $3.47 \pm 0.22$ & $26.50 \pm 1.60$ \\
\hline 10 & 11.29 & 3-octen-2-one & $18402-82-9$ & - & $1.07 \pm 0.09$ & - \\
\hline 11 & 12.89 & 2-Nonanone & $821-55-6$ & - & $2.81 \pm 0.21$ & - \\
\hline 12 & 13.32 & Nonanal & $124-19-6$ & $7.96 \pm 1.01$ & $3.29 \pm 0.42$ & $9.53 \pm 1.05$ \\
\hline 13 & 15.58 & 2-Heptenal, 2-propyl- & $34880-43-8$ & - & $1.17 \pm 0.06$ & - \\
\hline 14 & 15.85 & 2-Decanone & $693-54-9$ & - & $0.91 \pm 0.12$ & - \\
\hline 15 & 16.28 & Decanal & $112-31-2$ & $2.79 \pm 0.05$ & $1.36 \pm 0.26$ & - \\
\hline 16 & 19.00 & 2-Undecanone & $112-12-9$ & $1.06 \pm 0.18$ & - & - \\
\hline 17 & 19.51 & Undecanal & $11-44-7$ & - & - & $1.97 \pm 0.06$ \\
\hline 18 & 21.23 & 2-Octenal, 2-butyl- & 13019-16-4 & - & $7.58 \pm 0.88$ & - \\
\hline 19 & 22.11 & Dodecanal & $112-54-9$ & - & - & $1.21 \pm 0.05$ \\
\hline \multicolumn{3}{|c|}{ Total aldehydes-ketones } & & 20.67 & 45.91 & 42.15 \\
\hline \multicolumn{7}{|c|}{\begin{tabular}{l|l|l|} 
Esters & & \\
\end{tabular}} \\
\hline 20 & 7.66 & $\begin{array}{c}\text { Aceticacid, pentyl } \\
\text { ester }\end{array}$ & $628-63-7$ & - & $0.36 \pm 0.02$ & - \\
\hline 21 & 32.85 & $\begin{array}{c}\text { 9,12,15-Octadeca- } \\
\text { trienoic acid 2-trime- } \\
\text { thylsilyloxy-1- } \\
\text { [(trimethylsilyloxy) } \\
\text { methyl]ethyl ester } \\
\end{array}$ & $55521-23-8$ & - & $1.39 \pm 0.00$ & - \\
\hline \multicolumn{3}{|c|}{ Total esters } & & - & 1.75 & - \\
\hline \multicolumn{7}{|c|}{ Alkanes-heterocycliccompounds } \\
\hline 22 & 5.15 & $\begin{array}{c}\text { Hexamethylcyclo- } \\
\text { trisiloxane }\end{array}$ & $541-05-9$ & - & - & $2.26 \pm 0.16$ \\
\hline 23 & 6.51 & p-Xylene & $106-42-3$ & - & - & $1.36 \pm 0.30$ \\
\hline 24 & 7.13 & Guanosine, 2'-deoxy- & $961-07-9$ & - & - & $1.15 \pm 0.09$ \\
\hline 25 & 9.89 & 2-pentylfuran & $3777-69-3$ & $15.71 \pm 2.24$ & $16.30 \pm 1.22$ & - \\
\hline
\end{tabular}




\begin{tabular}{|c|c|c|c|c|c|c|}
\hline & & & & $\begin{array}{c}\text { Mycenastrum } \\
\text { corium }\end{array}$ & $\begin{array}{c}\text { Paxina } \\
\text { queletii }\end{array}$ & $\begin{array}{c}\text { Chlorophyllum } \\
\text { agaricoides }\end{array}$ \\
\hline $\mathbf{2 6}$ & 10.60 & Serotonin & $50-67-9$ & - & - & $0.50 \pm 0.00$ \\
\hline $\mathbf{2 7}$ & 10.93 & o-Cymene & $527-84-4$ & - & $0.80 \pm 0.15$ & - \\
\hline $\mathbf{2 8}$ & 11.08 & 2-Carene & $554-61-0$ & - & $6.10 \pm 0.74$ & $7.47 \pm 2.00$ \\
\hline $\mathbf{2 9}$ & 11.85 & Undecane & $1120-21-4$ & $2.49 \pm 0.35$ & - & $2.67 \pm 0.09$ \\
\hline $\mathbf{3 0}$ & 11.94 & y-terpinene & $99-85-4$ & - & $1.35 \pm 0.22$ & - \\
\hline $\mathbf{3 1}$ & 15.09 & Trehalose & $99-20-7$ & $1.02 \pm 0.42$ & - & - \\
\hline $\mathbf{3 2}$ & 15.66 & Azulene & $275-51-4$ & $1.00 \pm 0.09$ & - & $2.19 \pm 0.44$ \\
\hline $\mathbf{3 3}$ & 16.15 & Dodecane & $112-40-3$ & $4.10 \pm 0.24$ & $1.09 \pm 0.00$ & $8.29 \pm 0.98$ \\
\hline $\mathbf{3 4}$ & 18.29 & Eucalyptol & $470-82-6$ & - & $7.92 \pm 2.08$ & - \\
\hline $\mathbf{3 5}$ & 19.95 & Pentadecane & $629-62-9$ & $1.55 \pm 0.12$ & - & - \\
\hline $\mathbf{3 6}$ & 21.94 & Tetradecane & $629-59-4$ & $2.17 \pm 0.60$ & $1.36 \pm 0.30$ & $8.01 \pm 0.29$ \\
\hline $\mathbf{3 7}$ & 24.36 & Eicosane & $112-95-8$ & $0.89 \pm 0.07$ & - & - \\
\hline $\mathbf{3 8}$ & 25.36 & Hexadecane & $544-76-3$ & - & & $1.70 \pm 0.09$ \\
\hline \multicolumn{2}{|c|}{ Total alkanes- } & & 28.93 & 34.92 & 35.77 \\
\hline heterocycliccompounds & & & & \\
\hline $\mathbf{3 9}$ & 17.96 & Nonanoic acid & $112-05-0$ & $22.40 \pm 3.10$ & - & $6.44 \pm 0.86$ \\
\hline $\mathbf{4 0}$ & 20.99 & Decanoic acid & $334-48-5$ & $5.39 \pm 0.63$ & - & $2.25 \pm 0.16$ \\
\hline $\mathbf{4 1}$ & 27.33 & Tetradecanoic acid & $544-63-8$ & $0.47 \pm 0.00$ & - & $0.47 \pm 0.06$ \\
\hline $\mathbf{4 2}$ & 29.53 & Hexadecanoic acid & $57-10-3$ & $0.35 \pm 0.09$ & - & $0.67 \pm 0.03$ \\
\hline $\begin{array}{l}\text { Total } \\
\text { acids }\end{array}$ & & & 28.61 & - & 9.83 \\
\hline
\end{tabular}

- : Not detected.

a RT: Retention time.

${ }^{b}$ Area \%: The ratio between the peak area of a particular component in the sample and all the sample components' total peak area.

'SD: Standard deviation.

This volatile compound was reported in Nordic wild edible mushrooms, nearly the same amount in Chanterelus cibarius and close to twice in Boletus edulis [57]. In the same study, in Chanterelus cibarius, Craterellus tubaeformis, and Lactarius camphoratus, the hexanal content was detected twice the value we found in Paxina queletii. Hexanal and nonanal are two of the volatile compounds common to mushrooms studied in Aisala et al. (2019), just as in our study [57]. Hexanal and nonanal are also known as oxidation indicators in oils and butter. Some volatile compounds have functional properties. 1-Octen-3-ol produced by Paxina queletii was used successfully to control dry bubble disease in Agaricus bisporus [60]. 
Volatile compounds in dried mushrooms were content 1-octen-3-ol, 3-octen-2-one, 1-octanol, 2-octenal, 2-butyl-, 3-octanone, etc. the consequence was on aroma and sweetness in edible mushrooms. However, in another studies, main volatile compounds in fresh mushrooms were C8 compounds, content 1-octen-3-ol, 3-octanol, 2-octen-1-ol, 1-octanol, 2-octenal, 3-octanone, etc. the result was in conformity with other reports focusing on aroma in edible fungus [59, 61-63].

Nonanoic acid, the main volatile of Mycenastrum corium, is used for biocontrol of plants' fungal diseases [64]. New herbicides and blossom thinners based on nonanoic acid started to be used as an alternative to synthetic chemical herbicides [65]. Mycenastrum corium has the acidest content compared to Chlorophyllum agaricoides. Benzaldehyde is the main volatile in Chlorophyllum agaricoides and reported that benzaldehyde could be degraded from benzoic acid during the samples' drying process [59].

Generally, mushrooms are widely grown and consumed as an important food source due to their taste, low calorie and high sodium content, and vitamin, mineral, phenolic antioxidative compound content. Therefore, it is important to know edible mushrooms and to explain their disease-healing properties and physiological and biological active ingredients [42, 66]. HPLC analysis revealed that gallic acid, naringin and trans-cinnamic were predominant major compounds identified in three mushroom species and the individual profile of the relevant compounds are presented in Figure 2.

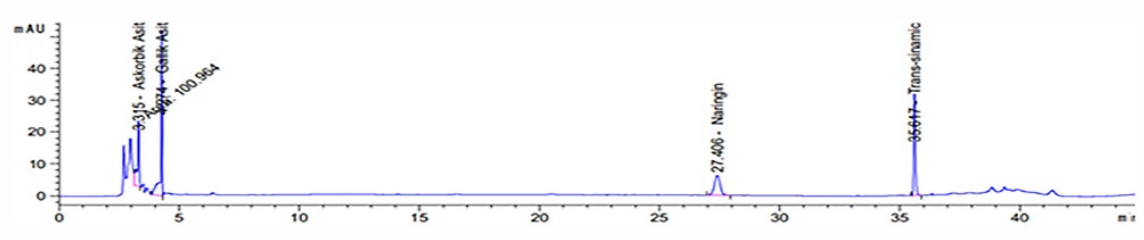

A
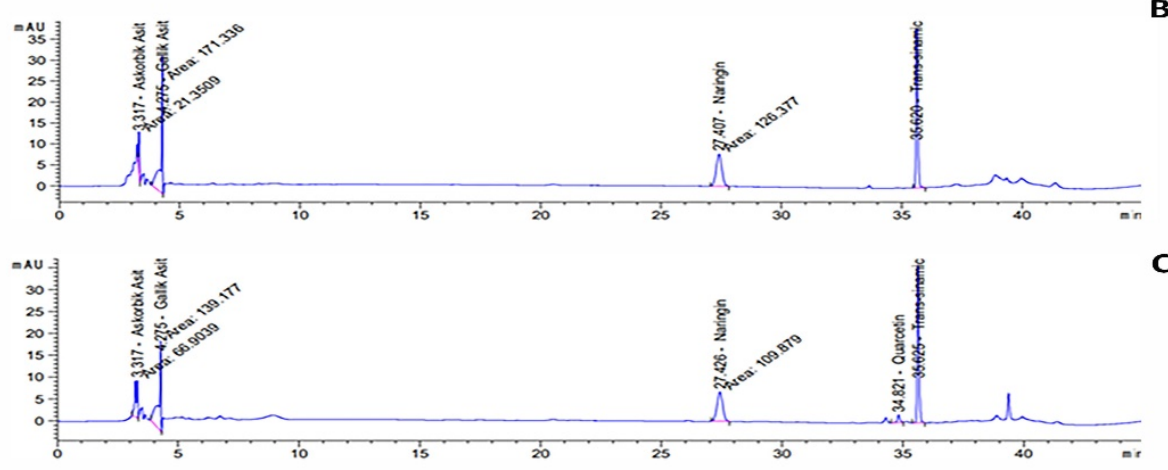

Figure 2. HPLC chromatogram of A) P. queletii, B) C.agaricoides and C) M. corium 
Of the revealed compounds, gallic acid is a naturally occurring low molecular weight triphenolic compound [67], being versatile for its biological functions, viz. radical quenching as well as interfering acts with cell-signaling pathways and in apoptosis of cancer cells [67]. Herewith the current findings, the highest content of gallic acid was observed in $P$. queletii $(12.4 \mu \mathrm{g} / \mathrm{ml})$ and followed by C.agaricoides $(10.32 \mu \mathrm{g} / \mathrm{ml})$ and $M$. corium $(8.22 \mu \mathrm{g} / \mathrm{ml})$. In relative to other mushroom species, gallic acid ranged between 5.4 and $38.9 \mathrm{mg} / \mathrm{g}$ extract in sequential extracts of Lycoperdon utriforme, suggesting that the content was solvent dependent [44]. Regarding naringin as a natural flavanone glycoside, multiple therapeutic effects, such as effect on genetic damage, central nervous system diseases, oxidative stress, and metabolic syndrome have been well-reviewed by Chen et al. (2016) [67]. Indeed, no big differences were observed in naringin content of the mushroom species herein (Table 3). Trans-cinnamic has been reported to possess antioxidant [68], antimicrobial [69, 70] and a-glucosidase inhibition [71]. As the case of naringin, the values of trans-cinnamic were close to each other.

Table 3. Phenolic acid profile of wild mushrooms extracts

\begin{tabular}{|l|c|c|c|}
\hline Compounds & $\boldsymbol{P}$. queletii & C.agaricoides & M. corium \\
\hline Gallic acid $(\boldsymbol{\mu g} / \mathbf{m l})$ & 12.4 & 10.32 & 8.22 \\
\hline Naringin $(\boldsymbol{\mu g} / \mathbf{m l})$ & 5.23 & 6.58 & 5.72 \\
\hline Trans-cinnamic $(\boldsymbol{\mu g} / \mathbf{m l})$ & 6.59 & 8.08 & 7.4 \\
\hline Quercetin $(\boldsymbol{\mu g} / \mathbf{m l})$ & ND & ND & 2.83 \\
\hline
\end{tabular}

ND: Not detected

\section{CONCLUSIONS}

The present study is the first report on chemical compositions and radical scavenging activities of three wild-edible mushroom samples including Paxina queletii, Chlorophyllum agaricoides and Mycenastrum corium from Turkey. Regarding antioxidant activities, in general, scavenging activities of mushrooms were lower in comparison to the former reports. 42 volatile compounds of Mycenastrum corium, Paxina queletii, and Chlorophyllum agaricoides were detected. The extracts were found as rich sources of alkanes-heterocyclic compounds (2-pentylfuran, 2-carene, $\mathrm{y}$-terpinene, azulene, dodecane, eucalyptol, pentadecane, tetradecane, eicosane, hexadecane), acids (nonanoic, decanoic, tetradecanoic, hexadecanoic acids), esters and aldehydes and ketones. Considering the phenolic acid composition, the extracts were found to be rich in gallic acid, naringin and trans-cinnamic. 


\section{EXPERIMENTAL SECTION}

\section{Materials}

Mushroom samples (Paxina queletii (Bres.) Stangl, Chlorophyllum agaricoides (Czern.) Vellinga and Mycenastrum corium (Guers.) Des. were collected from Zilan Valley (Erciş-Van, Turkey) (Table 4).

Table 4. The relevant information regarding species and their collection

\begin{tabular}{|l|c|c|c|c|}
\hline \multicolumn{1}{|c|}{$\begin{array}{c}\text { Mushroom } \\
\text { species }\end{array}$} & Altitude (m) & Coordinates & Location & Collection date \\
\hline $\begin{array}{l}\text { Paxina queletii } \\
\text { (Bres.) Stangl }\end{array}$ & 1860 & $\begin{array}{c}39^{\circ} 13^{\prime} 780^{\prime \prime N}, \\
43^{\circ} 23^{\prime} 560 " \mathrm{E}\end{array}$ & $\begin{array}{c}\text { Zilan Valley (Erciş- } \\
\text { Van, Turkey) }\end{array}$ & $2013-2014$ \\
\hline $\begin{array}{l}\text { Chlorophyllum } \\
\text { agaricoides } \\
\text { (Czern.) Vellinga }\end{array}$ & 1805 & $\begin{array}{c}39^{\circ} 09^{\prime} 991^{\prime \prime} \mathrm{N}, \\
43^{\circ} 19^{\prime} 614^{\prime \prime} \mathrm{Z}\end{array}$ & $\begin{array}{c}\text { Zilan Valley (Erciş- } \\
\text { Van, Turkey) }\end{array}$ & $2013-2014$ \\
\hline $\begin{array}{l}\text { Mycenastrum } \\
\text { corium (Guers.) } \\
\text { Desv. }\end{array}$ & 1835 & $\begin{array}{c}39^{\circ} 13^{\prime} 793^{\prime \prime N}, \\
43^{\circ} 23^{\prime} 575^{\prime \prime E}\end{array}$ & $\begin{array}{c}\text { Zilan Valley (Erciş- } \\
\text { Van, Turkey) }\end{array}$ & $2013-2014$ \\
\hline
\end{tabular}

After transferring to the laboratory and drying mushrooms at room temperature, the relevant mushroom samples were preserved in polyethylene bags at $-20^{\circ} \mathrm{C}$ until further analysis. The species (Figure 3 ) were defined by Mehmet Zeki Koçak and Deceased Prof. Dr. Kenan Demirel. A specimen was deposited in Mycology Research Fungarium, Faculty of Science, Van Yüzüncü Yıl University, Turkey (Fungarium codes: KOCAK 120, 155 and 106, respectively). All relevant chemicals used for analysis were purchased from Merck, unless otherwise stated. All chemicals were of HPLC grade.
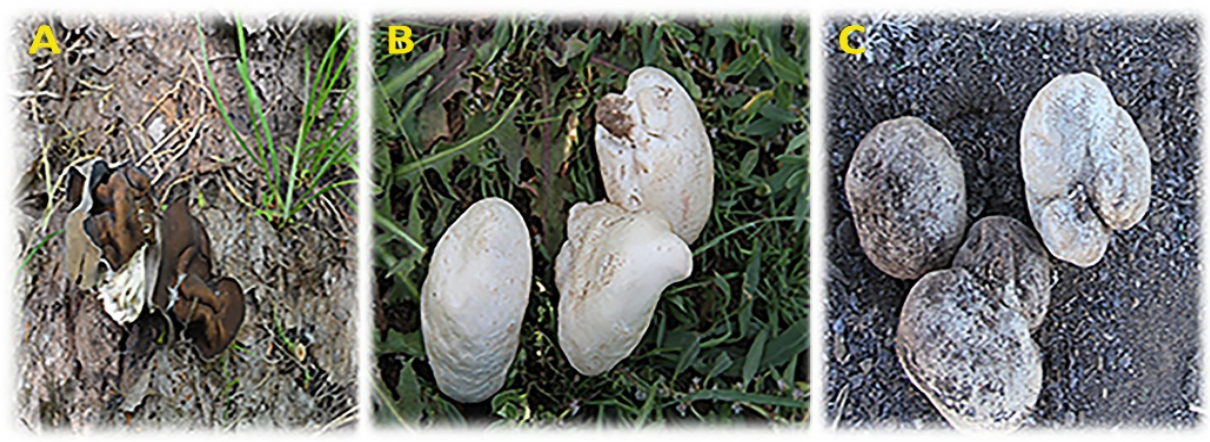

Figure 3. Edible mushroom materials of A) P. queletii, B) C. agaricoides and C) M. Corium 


\section{Determination of total phenolic (TPC) and total flavonoid contents (TFC)}

The TPC of ethanol extracts of mushrooms was determined based on Slinkard and Singleton (1977)'s method (FCR assay) [30]. Gallic acid (GA) $(1 \mathrm{mg} / \mathrm{ml})$ was used as the standard phenolic compound. TPC of extracts were calculated as milligrams of gallic acid equivalent (mg GAE/ g dried extract).

The TFC of extracts was determined according to the method described by Park et al. (1997) [31]. Quercetin $(0.1 \mathrm{mg} / \mathrm{ml})$ was used as the standard flavonoid compound. TFC of the extracts was calculated as milligrams of quercetin equivalent ( $\mathrm{mg} \mathrm{QE} / \mathrm{g}$ dried extract).

\section{Radical scavenging activities}

The 1,1-diphenyl-2-picryl hydrazyl (DPPH') radical scavenging activities were assayed according to method put by Brand-Williams et al. (1995) [32] with some modifications [33]. Alcohol solution of $\mathrm{DPPH}^{\circ}$ was added to various concentrations of mushrooms extracts ranging from $5 \mu \mathrm{g} / \mathrm{ml}$ to 14.5 $\mu \mathrm{g} / \mathrm{ml}$. The sample tubes were kept at room temperature in the dark and after $30 \mathrm{~min}$ the absorbance were measured at $517 \mathrm{~nm}$. Both $\mathrm{IC}_{50}$ values and scavenging percentages of the extracts and standard chemicals regarding $\mathrm{DPPH}^{-}$scavenging were calculated in order to compare with the literature.

The 2,2'-azino-bis [3-ethylbenzothiazoline-6-sulphonic acid] (ABTS'+) scavenging activities of the mushroom extracts were determined according to the method described by Cemeroğlu (2010) [34]. After ABTS ${ }^{+}$solution was prepared absorbance of blank sample was adjusted to $0.700 \pm 0.025$ at $734 \mathrm{~nm}$ in the spectrophotometer by diluting with $20 \mathrm{mM}$ acetate buffer (including $2.45 \mathrm{mM}$ potassium persulfate). The concentrations ranging from $30 \mu \mathrm{g} / \mathrm{ml}$ to $55 \mu \mathrm{g} / \mathrm{ml}$ of mushroom extracts were assayed. The $\mathrm{IC}_{50}$ values for each mushroom was quantified and also, scavenging percentages of the extracts and standard chemicals were calculated.

\section{Analysis of volatile compounds}

A $2 \mathrm{~cm}(50 / 30 \mu \mathrm{m}$ divinylbenzene/carboxen/polydimethylsiloxane) SPME fiber (Supelco Co., Bellefonte, PA, USA) was used for the extraction of volatile compounds from samples. $5 \mathrm{ml}$ of the ultra-pure water was added to $0.5 \mathrm{~g}$ of the sample in the glass vials (Supelco, USA) and allowed to equilibrate at $40^{\circ} \mathrm{C}$ for $30 \mathrm{~min}$ [35]. Identification of volatile compounds was performed with Thermo Fisher Trace ISQ GC-MS (USA) gas chromatographymass spectrometry system and run in split (ratio was 1:10) mode. The volatile compounds were separated on a DB-5MS column $(30 \mathrm{~m} \times 0.25 \mathrm{~mm} \times 0.25 \mu \mathrm{m}$; 
Agilent, USA). The oven was held at $40^{\circ} \mathrm{C}$ for $1 \mathrm{~min}$, then increased at $5^{\circ} \mathrm{C}$ per min to $120^{\circ} \mathrm{C}$, it was held for $2 \mathrm{~min}$, then rose again at $10^{\circ} \mathrm{C}$ per min to $240^{\circ} \mathrm{C}$ and caught $3 \mathrm{~min}$. The mass spectrometer was set to scan from 45 to $450 \mathrm{amu}$ (threshold 1000) at a sampling rate of 1.11 scans/s [36]. Compounds were identified by comparison to the Wiley 9 and Mainlib mass spectral libraries. The quantitative analysis was based on the ratios between the terminal area of a given component in the sample and the total terminal area of all components in the sample [35].

\section{Extraction and quantification of phenolic compounds using HPLC}

The relevant mushroom samples were firstly dried and then powdered. A shaker-assisted sequential extraction was performed with $5 \mathrm{mg}$ of fungus samples in $10 \mathrm{ml}$ methanol at $120 \mathrm{rpm}$ for 24 hours at room temperature. The extraction was repeated three times with the same materials to collect all residues after extraction. The filtrates of three extractions were evaporated using a rotary evaporator (Heidolph 94200, Bioblock Scientific). The vacuodried samples were preserved at $+4^{\circ} \mathrm{C}$ until chromatographic analysis.

The methanol extracts of the relevant mushrooms were filtered through a $0.45 \mu \mathrm{m}$ disk prior to HPLC analysis. For analysis, Agilent 1260 CA, USA series liquid chromatograph equipped with a diode array detector was used. The separation was performed using $10 \mu \mathrm{L}$ of extract on a ACE Generix 5C18 (GEN-7444) Scotland, column $(4.6 \times 250 \mathrm{~mm}, 5 \mu \mathrm{m})$ thermos stated at $30^{\circ} \mathrm{C}$. The mobile phase was (A) $0.1 \%$ phosphoric acid in water and (B) HPLC-grade $100 \%$ acetonitrile. The gradient was performed as specified in Table 5. The relevant phenolics were quantified with the comparing of the peak recorded at $300 \mathrm{~nm}$ with the standard curves of each acid. The calibration curves were obtained from a concentration range between 20$1000 \mu \mathrm{g} / \mathrm{ml}$ and $0.5-50 \mu \mathrm{g} / \mathrm{ml}$ for Gallic acid, naringin and trans-cinnamic. The results are expressed in $\mu \mathrm{g}$ per $\mathrm{ml}$ of dry mushroom.

Table 5. HPLC conditions

\begin{tabular}{|c|c|c|c|}
\hline Time (min.) & \multicolumn{2}{|c|}{ Solvent \% } & \multirow{2}{*}{$\begin{array}{c}\text { Flow Rate } \\
\text { (mL/min) }\end{array}$} \\
\cline { 2 - 3 } & A & B & 0.8 \\
\hline $\mathbf{0}$ & 83 & 17 & 0.8 \\
\hline $\mathbf{7}$ & 85 & 15 & 0.8 \\
\hline $\mathbf{2 0}$ & 85 & 15 & 0.8 \\
\hline $\mathbf{2 4}$ & 70 & 30 & 0.8 \\
\hline $\mathbf{3 0}$ & 65 & 35 & 0.8 \\
\hline $\mathbf{4 0}$ & 83 & 17 & \\
\hline
\end{tabular}

A: $0.1 \%$ phosphoric acid in water

B: HPLC-grade $100 \%$ acetonitrile 


\section{ACKNOWLEDGMENTS}

The taxonomic definition of wild mushroom species used in this study has been enlightened in M. Z. K.'s master's thesis. The analyses performed in the article were later designed and carried out. The authors thank to Dr. Muhittin Kulak for language editing of manuscript.

\section{Author Contribution}

MZK: Field survey, collection and identification of the species, elemental and phenolic analysis, co-writing of the draft; AMK: Co-writing of the draft, formal analysis; MK: GC-MS analysis, co-writing of the draft; UG: Antioxidant analysis, co-writing of the draft. All co-authors read and approved the last draft for submission.

\section{Conflicts of interest}

There are no conflicts to declare.

\section{REFERENCES}

1. M. Dimitrijević; V. Stankov Jovanović; J. Cvetković; M. Mitić; G. Petrović; A. Đorđević, and V. Mitić; Anal. Lett., 2017, 50(10), 1691-1709.

2. M. Zhang; S. Cui; P. Cheung, and Q. Wang; Trends Food Sci. Technol., 2007, 18(1), 4-19.

3. J. Falandysz and J. Borovička; Appl. Microbiol. Biotechnol., 2013, 97(2), 477-501.

4. A.S. Bengu; Prog. Nutr., 2019, 21(1), 189-193.

5. M.J. Feeney; A.M. Miller, and P. Roupas; Nutr. today, 2014, 49(6), 301.

6. P. Kalač; J. Sci. Food Agric., 2013, 93(2), 209-218.

7. W.M. Breene; J. Food Protect., 1990, 53(10), 883-894.

8. E.E. Ak; Y. Tüzel; E. Eren, and F. Atilla; Türk Tarım-Gıda Bilim ve Teknoloji dergisi, 2016, 4(3), 239-243.

9. S.N. Lotfy; H.H. Fadel; A.H. El-Ghorab, and M.S. Shaheen; Food Chem., 2015, 187, 7-13.

10. H.N. Bao; H. Ushio, and T. Ohshima; J. Agric. Food Chem., 2008, 56(21), 1003210040.

11. C.L. Dikeman; L.L. Bauer; E.A. Flickinger, and G.C. Fahey; J. Agric. Food Chem., 2005, 53(4), 1130-1138.

12. P. Kalač and L.r. Svoboda; Food chemistry, 2000, 69(3), 273-281.

13. W.Y. Lee; E.-J. Park; J.K. Ahn, and K.-H. Ka; Mycobiology, 2009, 37(1), 43-47.

14. A.S. Logan; U. Nienaber, and X.S. Pan; Lipid oxidation: Challenges in food systems. 2015, Elsevier.

15. A.J. Weigand-Heller; P.M. Kris-Etherton, and R.B. Beelman; Prev. Med., 2012, 54, S75-S78.

16. L. Barros; M.-J. Ferreira; B. Queiros; I.C. Ferreira, and P. Baptista; Food Chem., 2007, 103(2), 413-419. 
17. S. Khatun; A. Islam; U. Cakilcioglu; P. Guler, and N.C. Chatterjee; NJASWageningen J. Life Sci., 2015, 72, 1-5.

18. C. Rice-Evans; N. Miller, and G. Paganga; Trends Plant Sci., 1997, 2(4), 152-159.

19. E. Bernaś; G. Jaworska, and Z. Lisiewska; Acta Scientiarum Polonorum Technologia Alimentaria, 2006, 5(1), 5-20.

20. I. Fasidi and M. Kadiri; Food/Nahrung, 1990, 34(5), 415-420.

21. H. Sivrikaya; L. Bacak; A. Saraçbaşı; I. Toroğlu, and H. Eroğlu; Food Chem., 2002, 79(2), 173-176.

22. S. Hazama; S. Watanabe; M. Ohashi; M. Yagi; M. Suzuki; K. Matsuda; T. Yamamoto; Y. Suga; T. Suga, and S. Nakazawa; Anticancer Res., 2009, 29(7), 2611-2617.

23. P. Yang; M. Liang; Y. Zhang, and B. Shen; Adv. Ther., 2008, 25(8), 787-794.

24. P. Kalač; Food Chem., 2009, 113(1), 9-16.

25. R. Genders; Mushroom growing for everyone. 1982, Faber and Faber.

26. P. Oei; Manual on mushroom cultivation: techniques, species and opportunities for commercial application in developing countries. 1991, Tool.

27. A. Turkoglu; M.E. Duru; N. Mercan; I. Kivrak, and K. Gezer; Food Chem., 2007, 101(1), 267-273.

28. S. Kavishree; J. Hemavathy; B. Lokesh; M. Shashirekha, and S. Rajarathnam; Food Chem., 2008, 106(2), 597-602.

29. B. Ribeiro; R. Lopes; P.B. Andrade; R.M. Seabra; R.F. Gonçalves; P. Baptista, and I. Quelhas; Food Chem., 2008, 110(1), 47-56.

30. K. Slinkard and V.L. Singleton; Am. J. Enol. Vitic., 1977, 28(1), 49-55.

31. Y.K. Park; M.H. Koo; M. Ikegaki, and J. Contado; Arq. Biol. Tecnol, 1997, 97-106.

32. W. Brand-Williams; M.-E. Cuvelier, and C. Berset; LWT-Food Sci Technol., 1995, 28(1), 25-30.

33. U. Güller; P. Güller, and M. Çiftci; Alternative Therapies in Health and Medicine, 2020.

34. B. Cemeroğlu; Gıda Analizleri (Editör: B. Cemeroğlu). Ankara, Türkiye: Gıda Teknolojisi Derneği Yayınları, 2010, (34), 87-93.

35. Y. Tian; Y. Zhao; J. Huang; H. Zeng, and B. Zheng; Food Chem., 2016, 197, 714-722.

36. M. Koyuncu and Y. Tuncturk; Oxidation Commun., 2017, 40(2), 785-798.

37. S.P. Wasser and A.L. Weis; Critical Reviews ${ }^{\mathrm{TM}}$ in Immunology, 1999, 19(1).

38. N.G. Puttaraju; S.U. Venkateshaiah; S.M. Dharmesh; S.M.N. Urs, and R. Somasundaram; J. Agric. Food Chem., 2006, 54(26), 9764-9772.

39. P. Roupas; J. Keogh; M. Noakes; C. Margetts, and P. Taylor; J. Funct. Foods, 2012, 4(4), 687-709.

40. D. Stojković; F.S. Reis; L. Barros; J. Glamočlija; A. Ćirić; L.J. van Griensven; M. Soković, and I.C. Ferreira; Food Chem.Toxicol., 2013, 59, 289-296.

41. K. Liu; X. Xiao; J. Wang; C.-Y.O. Chen, and H. Hu; LWT-Food Sci. Technol., 2017, 82, 154-161.

42. L. Smolskaitė; P.R. Venskutonis, and T. Talou; LWT-Food Sci. Technol., 2015, $60(1), 462-471$.

43. J. Liu; L. Jia; J. Kan, and C.-h. Jin; Food Chem. Toxicol., 2013, 51, 310-316. 
44. S. Sezgin; A. Dalar, and Y. Uzun; J. Food Sci. Technol., 2020, 57(5):1866-1876.

45. J. Azieana; M. Universiti Teknologi; S. Alam; M. Universiti Teknologi; S. Alam; M. Universiti Teknologi; S. Alam; M. Universiti Teknologi, and S. Alam; Open Access Library Journal, 2017, 4(11), 1.

46. E. López-Vázquez; F. Prieto-García; M. Gayosso-Canales; E.O. Sánchez, and J.V. Ibarra; Italian J. Food Sci., 2017, 29(4).

47. D.A. Abugri and W.H. McElhenney; J Nat Prod Plant Resour, 2013, 3(3), 37-42.

48. C. Gan; N.B. Amira, and R. Asmah; Int. Food Res. J., 2013, 20(3), 1095.

49. F.C. Wong; T.-T. Chai; S.-L. Tan, and A.-L. Yong; Tropical J. Pharm. Res., 2013, 12(6), 1011-1016.

50. L. Barros; S. Falcão; P. Baptista; C. Freire; M. Vilas-Boas, and I.C. Ferreira; Food Chem., 2008, 111(1), 61-66.

51. A.C. Ramírez-Anguiano; S. Santoyo; G. Reglero, and C. Soler-Rivas; J. Sci.Food Agric., 2007, 87(12), 2272-2278.

52. F.S. Reis; A. Martins; L. Barros, and I.C. Ferreira; Food Chem. Toxicol., 2012, 50(5), 1201-1207.

53. J.M. Savoie; N. Minvielle, and M.L. Largeteau; J. Sci. Food Agric., 2008, 88(6), 970-975.

54. A. Dundar; V. Okumus; S. Ozdemir; K.S. Celik; M. Boga; E. Ozcagli; G. Ozhan, and A. Yildiz; J. Horticulture, 2015, 1-6.

55. G. Tel; M. Ozturk; M.E. Duru, and A. Turkoglu; Pharm. Biol., 2015, 53(6), 824-830.

56. G. Tel; E. Deveci; S. Küçükaydın; M.A. Özler; M.E. Duru, and M. Harmandar; Eurasian J. Anal. Chem., 2014, 8(3), 136-147.

57. H. Aisala; J. Sola; A. Hopia; K.M. Linderborg, and M. Sandell; Food Chem., 2019, 283, 566-578.

58. R.L. Berendsen; S.I. Kalkhove; L.G. Lugones; J.J. Baars; H.A. Wösten, and P.A. Bakker; Appl. Microbiol. Biotechnol., 2013, 97(12), 5535-5543.

59. F. Pei; W. Yang; N. Ma; Y. Fang; L. Zhao; X. An; Z. Xin, and Q. Hu; LWT-Food Sci. Technol., 2016, 72, 343-350.

60. J.L. Mau; R.B. Beelman, and G.R. Zigler; J. Food Sci., 1992, 57(3), 704-706.

61. M. Aneja; T.J. Gianfagna, and P.K. Hebbar; Physiol. Mol. Plant Pathol., 2005, 67(6), 304-307.

62. J. Bennett; R. Hung; S. Lee, and S. Padhi; Fungal associations, 2012, 373-393.

63. S. Grosshauser and P. Schieberle; J. Agric. Food Chem., 2013, 61(16), 3804-3813.

64. R. Ciriminna; A. Fidalgo; L.M. Ilharco, and M. Pagliaro; Biofuel Bioprod Biorefin, 2019, 13(6), 1476-1482.

65. S. Sezgin; A. Dalar, and U. Yusuf; Int. J. Second. Metab., 2018, 5(2), 163-170.

66. B. Badhani; N. Sharma, and R. Kakkar; Rsc Advances, 2015, 5(35), 2754027557.

67. R. Chen; Q.-L. Qi; M.-T. Wang, and Q.-Y. Li; Pharm. Biol., 2016, 54(12), 32033210.

68. M. Sova; Mini Rev. Med. Chem., 2012, 12(8), 749-767.

69. K.S. Letsididi; Z. Lou; R. Letsididi; K. Mohammed, and B.L. Maguy; Lwt, 2018, 94, 25-32. 
AHMET METIN KUMLAY, MEHMET ZEKI KOÇAK, MUBIN KOYUNCU, UĞUR GÜLLER

70. S. Yilmaz; M. Sova, and S. Ergün; J. Appl. Microbiol., 2018, 125(6), 1714-1727.

71. S. Adisakwattana; K. Sookkongwaree; S. Roengsumran; A. Petsom; N. Ngamrojnavanich; W. Chavasiri; S. Deesamer, and S. Yibchok-anun; Bioorg. Med. Chem. Lett., 2004, 14(11), 2893-2896. 